\title{
Gender Differences In Adjustment Issues, Quality Of Life And Psychological Resilience Among Hostel Students
}

\author{
Daniya Hasan \\ Umm E Rubab Kazmi \\ \& \\ Kanzal Jawahir \\ Department of Applied Psychology \\ Lahore College for Women University
}

\begin{abstract}
The present study explores gender differences in adjustment issues, quality of life and psychological resilience among hostel students. Purposive sampling was used and 400 hostel students (female $=183$ and male $=217$ ) were taken from public and private sector colleges/universities. Students from 1st year, BS (year1) and MS (year1) with 18-25 years were taken. The College Adjustment Test CAT was translated in Urdu language and administered on the students along with PR, Short form survey (SF-36) and demographic form. Results show that reliability of the scales was found to be significant CAT $\alpha=0.72$, SF-36 $\alpha=0.80$ and PR $\alpha=0.62$. The first hypothesis showed significant result $(p=0.03)$ that $1^{\text {st }}$ year students tend to face more adjustment issues rather than BS (year 1). The second hypothesis verified that female students encounter more adjustment problems as compared to male students. Male students show higher psychological resilience (PR) as compared to female students. While there are no gender differences found on the variable of QOL which was assessed through SF-36. PR showed negative correlation with adjustment issues $\mathrm{r}=-0.11$ and $\mathrm{SF}-36 \mathrm{r}=0.20$. This research will help university administrators, counselors and student affair officers to design appropriate policy/ programs with varieties of support packages to address the needs of the students.
\end{abstract}

Keywords: Adjustment Issues, Quality of Life, Psychological Resilience.

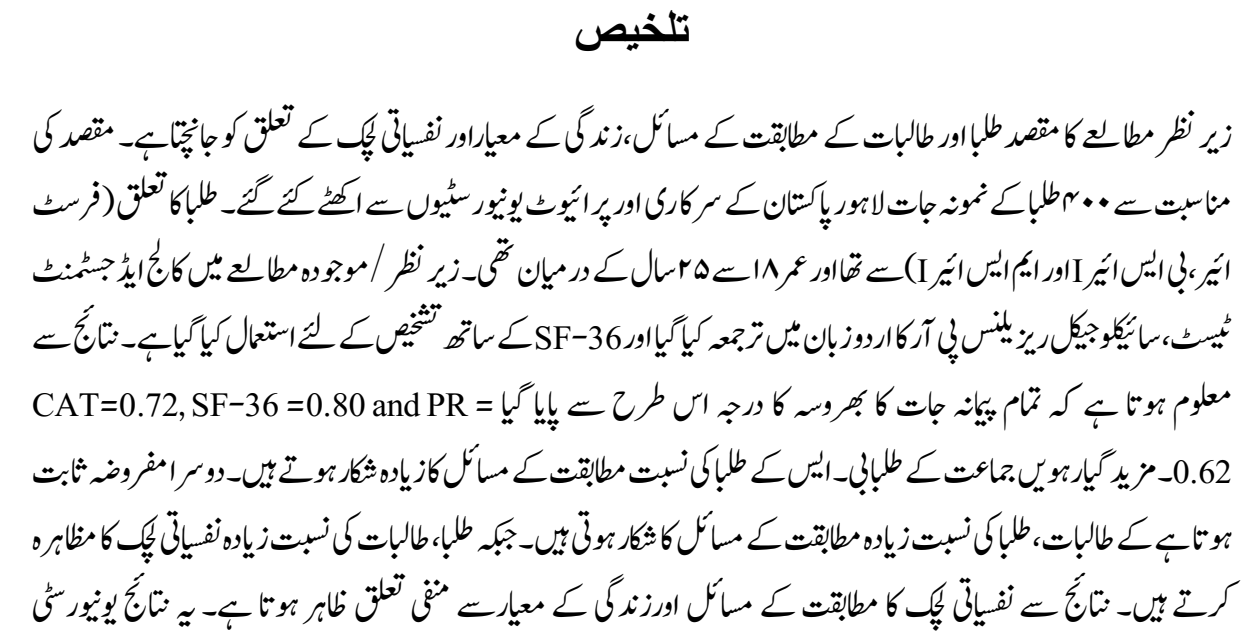




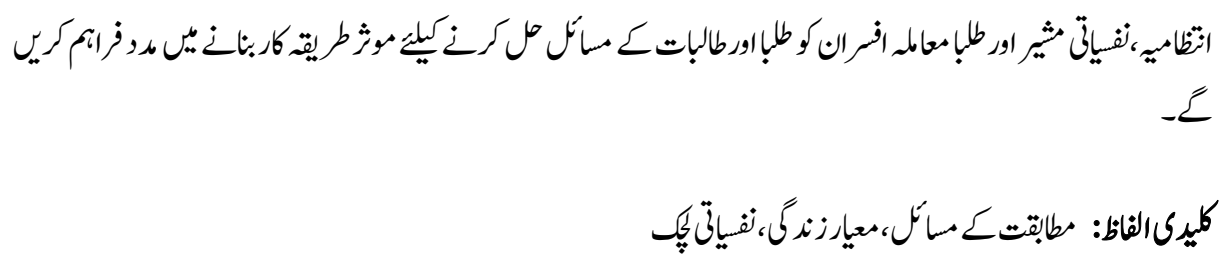

\section{Introduction}

Transition from school to college is difficult and has an impact on the adjustment of student. There are many factors that influence the students adjustment whether they are living with parents and residing in hostels e.g. loneliness, freedom, confusion, competition, homesickness (Dennis, Phinney \& Chuateco, 2005; Moore, 2006, \& Tuna, 2009) student teacher interaction, difficulty in concentrating (Yalew, 2003) feeling oneself inferior from other classmates, feeling anxious (Fischer, 2009).

Students in hostels are more affected by these adjustment challenges as compared to students living with parents. Homesickness is the most common problem faced by students who are residing in hostels. A research indicated that more or less $90 \%$ of the students usually experience some sort of homesickness (Urani, Miller \& Johoson, 2003). Watton (2001) reported that students residing with their families tend to adjust more rather than students who reside in hostels. All of these above mentioned factors have an impact on one's quality of life (QoL). QoL is defined as one's subjective view about positive and negative dimensions of life (WHO, 1998). It includes psychological and physical aspects which combine have an impact on satisfaction with life (Diener, 1984; Diener, Suh, Lucas \& Smith, 1999).

To have better quality of life, a person must be resilient. Mowbray (2011) defined resilience as the bouncing back from a dreadful event, i.e., to have the potential to deal with or the capability of a person to look at things through the end. According to him, resilience is all about the survival, endurance and growth from the situation. Psychological resilience among students refers to the ability to cope or fight the difficulties and complications such as notes taking, preparation for exams, presentation anxiety etc related to academic life (Wasonga, Christman \& Kilmer, 2003). It is a mechanism that works or survives in the presence of stressful event (Bonanno, 2004 \& Masten, 2001). All these factors significantly contribute to student adjustment to college.

This area has not been explored in Pakistan especially with reference to hostel students. This research will be helpful for university administration/campus counselors to assess the problems of hostel students and to provide them counseling regarding their problems.

\section{Literature Review}

Adjustment problems occur when students are unable to deal with societal, educational and psychological burden successfully. There are gender differences seen in this regard 
as Lama (2010) reported that the female students have greater tendency to encounter adjustment problems than the male students. It is seen that students reside in hostels experience more adjustment problems because they are far away from their homes. Hostel students experience many adjustment issues such as new setups, security problems, accommodation issues, transport system, loneliness, difficulty to interact with new people (Berry \& Sam, 2006).

Adler, Raju, Beveridge, Wang, Zhu and Zimmermann (2008) assumed that students' poor performance in their later life correlated with adjustment problems experienced in their student life. The inability to cope or adapt to these stressors and responds negatively to these stressors linked with bad quality of life.

The quality of life is affected by several factors such as physical or psychological health concerns, sleep problems, homesickness, social issue, relational problems, education, accommodation problems, personal beliefs and other environmental features (Ruzevicius, 2006; Juozulynas \& Cemerych, 2005). Madhuchandra and Srimathi (2017) conducted research on psychological health and illness among college students. Results reveal that female college students are more socially dysfunctional as compared to male students while male students are more severely depressed than female students.

Academic performance and psychological resilience are correlated with each other. This connection is seen through the research carried out by Allan (2014). On the sample of 1534 students it was concluded that there is a link between academic performance and resilience. He further revealed that female students have more resilience power than male students.

It was seen that students having no/low resilience power were more prone to adjustment problems as compared to those with resilient capabilities (Rouse, Ingersoll, \& Orr, 1998). Contradictory findings of another study by Erdogan, Ozdogan and Erdogan (2015) highlighted gender differences that male students are more resilient than female students.

The objective of the study is to explore the gender differences in adjustment problems, quality of life and psychological resilience among hostel students. The study is significant in a sense that it will assess and rule out some implications/recommendations so that hostel students may get assistance.

\section{Hypothesis}

It was hypothesized that

- First year students would face more adjustment problems as compared to BS (year 1) students. 
- Female students would face more adjustment problems, poor quality of life and psychological resilience as compared to male students.

- There would be negative correlation between psychological resilience and adjustment problems.

\section{Method \\ Research design}

Cross sectional research design was used.

\section{Sampling strategy}

Purposive sampling strategy was employed.

\section{Sample}

Sample was consisted of 400 hostel students. Total 52\% were residing in private hostels while $48 \%$ were from university hostels. Intermediate students were $36.5 \%$, BS $31.5 \%$ and from $32.0 \% \mathrm{MS}$.

\section{Criteria of inclusion}

Hostel students of $1^{\text {st }}$ year, BS (year 1) and MS (year 1) with age range of 18-26 years.

\section{Measures}

Following were the measures of study.

Written Consent Form: Was duly filled and signed by all participants of the study.

Demographic Sheet: It includes age, gender, hostel details, occupation of parents, whether living or dead, names of friends or hostel inmates, name of home-town, marital status, education and so on.

PR Scale: Urdu translated version of PR scale was used (Jawahir \& Kazmi, 2013). The scale was originally developed by Windle, Markland and Woods (2008). This scale is made up of mutual control taken from Paulhaus Spheres of Control, self esteem extracted from Rosenberg Self Esteem scale and personal competency/efficacy scales extracted from Wagnild and Young Resilience Scale respectively. Three scales were picked from the aforesaid scales i.e Competence (consists of 6 items), interpersonal Control (consists of 5 items) and self-esteem (consists of 8 items). In total, It consists of 19 variables which 
employ a 5 point Likert rating, starting from 1 (strongly agree) to 5 (strongly disagree). The reliability of the final scale is 0.83 .

CAT: This test was created by Pennebaker (1990) which ascertains a person's stage in life, mood, shyness/confidence and assumptions of personality to improve coping process in college i.e. college adjustment. It comprises of 19 variables which quantify the number of students who felt ad reflected in different manner as far as college attended in the prior week was concerned. positive effect, negative effect and homesickness were the principal characteristics that were visible. 0.79 is the internal consistency of the full scale with 0.65 test retest reliability and Lexicon equivalence method was used for translation of this scale into urdu language.

SF-36: Short Form Survey (SF) developed by Ware (1993) which is a short, multipurpose survey comprising of 36 queries in Urdu language. It has 8-scale sketch of a person's well-being and basic health which assess mental and physical well-being. It is a general measure and does not cater to a particular age, illness or group under treatment. This scale was used to assess quality of life of students.

\section{Procedure}

Permission was requested from the Department of Applied Psychology, Lahore College for Women University. In addition to this, approval was also taken from authorities of the hostels. Total five (5) hostels permitted for data collection in which three (3) were university and two (2) were private hostels. Data was gathered by the kind cooperation of the staff of the hostels. Written consent was taken from students. Assurance was also given that the information taken would be solely used for research purposes. Demographic sheet along with CAT, SF 36, PR Scale were given to the participants. They were duly filled in, in about half an hour after giving them the requisite guidance. At the end, participants were acknowledged and thanked for their time, effort and providing the necessary data.

\section{Results}

The data of the study was statistically analyzed by using SPSS (20.00 version for windows). Demographic results of the sample are as follows. Age categories were made according to Erikson stages of adolescent with $M=20.6, S D=2.59$. Furthermore, the participants for the study were female students $(54.3 \%)$ and male students $(45.8 \%)$ with $36.5 \%$ in Intermediate, $31.5 \%$ in BS and $32.0 \%$ in MS residing in three (3) university $(48.0 \%)$ and two (2) private hostels $(52.0 \%)$. The percentage of students from university hostels was $30 \%, 15 \%$ and $15 \%$. About $98.5 \%$ of the students were single and $1.5 \%$ was married. Moreover, most of the participants were from Punjab (80.8\%), 13.5\% from Sindh, 4.8\% from KPK and 1.0\% from Baluchistan. 


\section{Reliability of the Scales Used in the Study}

Cronbach's alpha was used to calculate the internal consistency of the scales that were translated into Urdu language which is shown in $\mathrm{Tb} 2$. This analysis revealed that CAT was highly significant (19 items: $\alpha=0.72$ ) with its sub scales revealing significant reliability i.e. homesickness consisting of 6 items $(\alpha=0.54)$, negative affect involving 9 items $(\alpha=0.81)$ and positive affect with 6 items $(\alpha=0.53)$. Moreover, PR also showed significant reliability $(\alpha=0.62)$ along with SF-36 $(\alpha=0.80)$ which reports highly significant internal consistency.

Table: 1

Correlation between CAT, SF-36 and PR

\begin{tabular}{|l|c|c|c|}
\hline Scales & $\mathbf{1}$ & $\mathbf{2}$ & $\mathbf{3}$ \\
\hline CAT & & & \\
\hline SF-36 & $0.20^{* *}$ & - & \\
\hline PR & $-0.11^{*}$ & -0.10 & \\
\hline
\end{tabular}

$* * P<0.01, \quad * P<0.05$

The analysis revealed positive correlation between CAT and SF-36 $r=0.20$, and a negative correlation between CAT and PR $r=-0.11$ as well as between SF-36 and PR $r$ $=-0.10$.

Table: 2

Correlation among subscales of SF-36, CAT and PR

\begin{tabular}{|l|c|c|c|c|c|c|c|c|}
\hline Subscales & $\mathbf{1}$ & $\mathbf{2}$ & $\mathbf{3}$ & $\mathbf{4}$ & $\mathbf{5}$ & $\mathbf{6}$ & $\mathbf{7}$ & $\mathbf{8}$ \\
\hline PCS & - & & & & & & & \\
\hline MCS & $-0.13^{* *}$ & - & & & & & & \\
\hline Homesickness & $-0.21^{* *}$ & 0.04 & - & & & & & \\
\hline Positive affect & 0.10 & -0.10 & 0.01 & - & & & & \\
\hline Negative Affect & $-0.20^{* *}$ & $0.15^{* *}$ & $0.60^{* *}$ & 0.05 & - & & & \\
\hline Self esteem & 0.10 & $0.24^{* *}$ & $-0.01^{* *}$ & $0.14^{* *}$ & -0.10 & - & & \\
\hline $\begin{array}{l}\text { Inter personal } \\
\text { control }\end{array}$ & $-0.20^{* *}$ & -0.04 & 0.10 & $-0.12^{*}$ & $0.14^{* *}$ & $-0.20^{* *}$ & - & \\
\hline Competence & $-0.21^{* *}$ & -0.10 & $0.20^{* *}$ & $-0.12^{*}$ & 0.10 & $-.03^{* *}$ & $0.40^{* *}$ & \\
\hline
\end{tabular}

$* * \mathrm{P}<0.01, * \mathrm{P}<0.05$ 
It revealed that there is significant positive relationship between negative affect and homesickness $r=0.60$ as well as between positive affect and physical component $r=$ 0.10. Significant negative relationship was found among interpersonal control, physical component $r=-0.20$ and self esteem $r=-0.20$.

Table 3

Comparison of means of male students and female students on CAT, SF-36 and PR

\begin{tabular}{|c|c|c|c|c|c|c|c|c|c|c|}
\hline \multirow[t]{2}{*}{ Measures } & \multicolumn{2}{|c|}{$\begin{array}{c}\text { Male } \\
\text { Students }^{\mathrm{a}}\end{array}$} & \multicolumn{2}{|c|}{$\begin{array}{c}\text { Female } \\
\text { Students }\end{array}$} & \multirow[t]{2}{*}{ df } & \multirow[t]{2}{*}{$\mathbf{t}$} & \multirow[t]{2}{*}{$\mathbf{p}$} & \multicolumn{2}{|c|}{$95 \%$ CI } & \multirow[t]{2}{*}{$\begin{array}{c}\text { Cohen's } \\
d\end{array}$} \\
\hline & M & SD & M & SD & & & & $\mathbf{L L}$ & UL & \\
\hline CAT & 66.24 & 12.04 & 73.82 & 14.74 & 398 & 5.66 & .000 & -10.21 & -4.95 & .30 \\
\hline SF-36 & 83.93 & 9.60 & 84.54 & 9.68 & 398 & 0.62 & .532 & -2.51 & -1.29 & 0.3 \\
\hline PR & 51.83 & 6.72 & 40.72 & 5.58 & 398 & 3.40 & .001 & 0.90 & 3.33 & .90 \\
\hline
\end{tabular}

Note. $\mathrm{CI}=$ Confidence Interval; $\mathrm{LL}=$ Lower Limit; $\mathrm{UL}=$ Upper Limit

${ }^{\mathrm{a}} \mathrm{n}=217,{ }^{\mathrm{b}} \mathrm{n}=183$

There is a significant difference between male and female students on mean scores of CAT. This shows that adjustment problems prevail more in females than males which proves hypothesis of the study. However, results also show that male students are more resilient than female students. While there are no gender differences found on SF-36.

Table: 4

Comparison of means of first year and BS (year 1) students on CAT

\begin{tabular}{|l|c|c|c|c|c|c|c|c|c|c|}
\hline \multirow{2}{*}{ Measures } & \multicolumn{2}{|c|}{ 1st Yeara } & \multicolumn{2}{|c|}{ BS (year 1)b } & \multirow{2}{*}{ df } & \multirow{2}{*}{$\mathbf{t}$} & \multirow{2}{*}{$\mathbf{p}$} & \multicolumn{2}{|c|}{$\mathbf{9 5 \%}$ CI } & Cohen's \\
\cline { 2 - 7 } & $\mathbf{M}$ & SD & $\mathbf{M}$ & SD & & & & S & SD & d \\
\hline CAT & 71.15 & 14.97 & 67.19 & 14.43 & 270 & 2.21 & 0.03 & 4.27 & 7.47 & 0.13 \\
\hline
\end{tabular}

$\mathrm{n}=146, \mathrm{n}=126$

This difference shows that adjustment issues are more faced by Intermediate students than BS students (Year 1).

\section{Table 5}

Comparison of Means of University hostel and Private hostel students on CAT

\begin{tabular}{|c|c|c|c|c|c|c|c|c|c|c|}
\hline \multirow[t]{2}{*}{ Measures } & \multicolumn{2}{|c|}{$\begin{array}{c}\text { University } \\
\text { Hostela }\end{array}$} & \multicolumn{2}{|c|}{$\begin{array}{l}\text { Private } \\
\text { Hostelb } \\
\end{array}$} & \multirow[t]{2}{*}{ df } & \multirow[t]{2}{*}{$\mathbf{t}$} & \multirow[t]{2}{*}{$\mathbf{p}$} & \multicolumn{2}{|c|}{$95 \% \mathrm{CI}$} & \multirow[t]{2}{*}{$\begin{array}{c}\text { Cohen's } \\
\text { d }\end{array}$} \\
\hline & $\mathbf{M}$ & SD & $\mathbf{M}$ & SD & & & & $\mathbf{L L}$ & $\mathbf{U L}$ & \\
\hline CAT & 67.27 & 13.37 & 71.96 & 13.94 & 398 & -3.42 & 0.001 & -7.37 & -1.99 & .17 \\
\hline
\end{tabular}

$\mathrm{n}^{\mathrm{a}}=192, \mathrm{n}^{\mathrm{b}}=208$

Table 5 shows that there is significant difference between means of private and university hostel students on CAT. Private hostel students tend to face more issues $(M=71.96$, 
$\mathrm{SD}=13.94)$ as compared to university hostel students $(\mathrm{M}=67.27, \mathrm{SD}=13.37), \mathrm{t}$ (398)

$=.001,95 \%$ CI $(-7.37,-1.99), \mathrm{d}=-0.17$

\section{Discussion}

Stepping into the college life is a significant period of life in anyone's life. Students confront a lot of issues pertaining to education and friendships especially adjustment issues in hostel. The current research explores the various adjustment problems, quality of life, and resilience level in Pakistani population that aids students in adjusting to the novel environment.

The study in question concludes that the adjustment problems are usually found in students in their first year of college instead of BS students in year one. This is because students confront more drastic change from school to college life and more problems are encountered in the very first year. As mentioned in earlier researches, students of $1^{\text {st }}$ year find college more problematic (58\%) as compared to those in their $3^{\text {rd }}$ year of college life $(39 \%)$. Main causes could be absence of social support and lack of emotional immaturity (Sharma, 2012). According to Enochs and Roland (2006), those pupils who lack social support are unable to make better adjustments to college life as compared to those who make new friendships and engage in social activities. Research also suggests that students who have the potential to engage in social groups have the ability to make adjustments in a better way and perform well in academics (Yau, 2012). Apart from this, there can be other factors like issues with mates, material sharing, and financial constraints that lead towards poor adjustments (Kabtamu, 2009). Mao and Mei (2008) concluded that major adjustment issues were seen among freshmen upon stepping into college life. Kabtamu (2009) found out that students during their first year are likely to confront more problems and some problems can be overwhelming such as interpersonal issues, academic problems, and poor teacher student bonding. These findings match to those found by Wang (2006) and Chong (2009) that state that family, society, and college life affects the adjustment during the first year. Mudhovozi (2012) found out that first year pupils are likely to have issue pertaining to families, social ties, food, and loss of contact with school friends and many more.

These problems of the students in the hostel result in disturbed patterns of living making the quality of life poor. In the present study, a positive correlation was seen among these variables and the hypothesis was thus accepted. As said in literature review, poor adjustment results in increased stress and makes adjustment more complicated (Wintre \&Yaffe, 2000). Peer and parental support aids students to make better adjustments but lack of such support results in issues in making adherence to new life around college. All this makes a student more anxious, depressed, and stressed (Cutrona, Cole, Colangelo, Souline \& Russel, 1994; Holahan, Valentiner, \& Moos, 1995). Another study states that homesickness is a major issue in a student's life and nearly $90 \%$ of the students face this problem (Urani, Miller \& Johnson, 2003). Other major factors that contribute in poor 
adjustment level include irregular sleeping patterns that also result in depression and less satisfaction with life activities (Pilcher \& Ott, 1998; Brown, Buboltz \& Soper, 2002). Students who are unable to make better social adjustments have low levels of self-esteem (Rice, 1999).Sharda (2003) when exploring relationship among student adjustment and mental health stated that positive perceptions of surroundings aid them to make better adjustments as compared to those having negative perceptions. Students who live in hostels are usually not satisfied with their lives and the major cause behind this could be that they are not adjusted to their environments and confront issues which act as obstacles in their way of having a quality life including non cleanliness, absence from classes, learning problems, and conveyance issues (Abolfotouh, Baasiouni, Mounir and Fayyad, 2007). Such adjustment issues are more common among female students as compared to male students.

The current study states that adjustment problems are more prevalent in females as compared to males, $p=0.000$. This statement is well supported by literature. Lama (2010) mentions female students face more hassles in way to adjustment than males. According to Enochs and Renk (2006), male pupils have the ability to make better adjustments than females and one major reason for this could be that women are more reliant on support and social groups. Likewise, Mudhovozi (2012) stated that majority of the females have feeling of loneliness. They also mentioned having more communication barriers and financial issues. Jemal (2012) confirmed that female students face more adjustment issues and are unable to make social participations.

Abolfotouh et al., (2007) stated that females have more issues when making adjustments to hostel life as compared to males because females face more difficulties to mobilize and are dependent on others for support. Abdullah, Elias, Mahyddin, and Uli (2009) also confirmed that males have the ability to make better adjustments to surroundings and female students have more issues when making social adjustments. They also discovered that males are better adjusted to surroundings as compared to females and this is because males have the ability to manage emotions and make settlements in a better way.

No significant gender differences were found on SF-36 score which was used to assess quality of life. The quality of life was seen to be affected for both female and male students in the same way which contradicts the findings that are present in literature. According to Greblo and Hodak (2012), male students score on health was higher than females. This shows that their quality of living was better than female students. Sabbah, Khamis and Droubi (2013), HRQoL was better for males rather than for females and their score was high on HRQoL. This could be possible because of more males in our society participating in daily households items along with females. Earlier, only females were responsible for every household matters but with passage of time, males support and provide helping hand to females, so the degree of disturbed QOL could be same for both the gender. In order to 
overcome these issues, students need to be resilient so they can achieve their tasks more easily and in proper manner.

The present study reveals that male students are more resilient as compared to females. The same findings revealed by Erdogan, Ozdogan and Erdogan (2015). Previous literature shows contradiction in gender differences on resilience. Fishman (2012) stated that female students are likely to have higher score on resilience. Likewise, Allan (2014) reported a correlation among resilience and performance and stated that positive aspects of resilience are more prevalent in female students as compared to male students. The major reason behind this contradiction can be cultural differences. Pakistani population is more emotional and females are likely to show strong emotions and are less exposed to social environments as compared to males that is why the level of resilience is found to be low.

The present research states that there is a negative relation between resilience of students and adjustment issues as well as quality of life. Earlier researches suggest that people who make use of emotion focused plans tend to have lesser achievements as compared to students making use of problem focused plans. So, in order to decrease the level of stress, students have to adapt to an effective technique that is significant for staying resilient (Ward Struthers \& colleagues, 2000). Researches have also mentioned that level of resilience in the students has to be updated so that stress factors can be minimized. Likewise, students who are not adjusted to their environment get involved in high risk activities and behaviors and such behaviors are common in non-resilient individuals (Rouse, Orr \& Ingersoll, 1998). Another research suggested that there is a relation between task oriented strategies, problem focused plans, and resilience that aids in dealing with various life stressors (Campbell-Sills \& colleagues, 2006). Similarly it has been discovered that there is an important relationship between academic behavior and such strategies. If a student tends to adhere to these strategies, it will aid him or her in achieving his goals (Clifton \& colleagues, 2004).

Like adjustment problems, QOL is also negatively correlated to levels of resilience. Literature suggests that adjustment to the society, homelessness, social groups, and academics are all components of QOL and all these components affect the academic achievements as well as overall health (Abdullah et al., 2009; Quinn, Madon \& Lusting, 2006).

Another analysis was made to see the differences of means on college adjustment for pupils living in university hostels and private hostels. The research reveals that those residing in university hostel face less issue as compared to those living on private hostels. This correlates to the findings in the previously mentioned literature. According to Pike (2009), students in university hostels have the ability to adapt to new changes in their lives. Likewise, another study found that university hostel students are more likely to participate in social activities 
and make better adjustments (Lundgren \& Schwab, 1979; cited in Rinn, 2004). Besides this, students in university hostels have more facilities and do not have conveyance issues. Such students are more contended. Major reason behind this could be that they reside within university premises and have feelings of association with those around them.

\section{Conclusions}

It is concluded on the basis of findings that adjustment problems are more prevalent in $1^{\text {st }}$ year students as compared to $3^{\text {rd }}$ year students. Female students face more adjustment problems as compared to male students. Level of resilience is higher in males as compared to females students. However, the findings of the study did not find gender differences in quality of life among the students.

\section{Limitations and Recommendations}

Following are the limitations of the present research and future considerations,

- Equal number of students was not taken from each hostel.

- Hostel environment along with facilities was not taken into consideration while interpreting results.

- The cultural differences bound the findings of this research to Lahore only.

- In future research, large number of hostels should be included for generalization of results.

- Counseling centers within university should be established so that intervening variables and stressors of students may be minimized.

\section{References}

Abdullah, M. C., Elias,H., Mahayuddin, R. \& Uli, J. (2009). Adjustment among First Year Students in Malaysian University. European Journal of Social Sciences, vol.8:3, pp.496-505.

Abolfotouh, M. A., Bassiouni, F. A., Mounir, G. M. \& Fayyad, R.Ch. (2007). HealthRelated Lifestyles and Risk Behaviors among Students Living in Alexandria University Hostels. Eastern Mediterranean Health Journal, vol.13:2, pp.376-391.

Adler, J., Raju, S., Beveridge, A. S., Wang, S., Zhu, J. \& Zimmermann, E. M. (2008). College Adjustment in University of Michigan Students with Crohn's and Colitis. Inflammatory Bowel Diseases, vol.14:9, pp.1281-1286. 
Allan, J. (2014). Resilient Female Students Outperform Male Counterparts. British Journal of Guidance and Counselling, (310).

Berry, J.W. \& Sam, D.L. (2006). The Cambridge Handbook of Acculturation Psychology. UK: Cambridge University Press.

Bonanno, G.A. (2004). Loss, Trauma, and Human Resilience: Have We Underestimated the Human Capacity to Thrive after Extremely Aversive Events?.Am Psychol, vol.59:1, pp.20-28.

Brown, F., Buboltz, W. \& Soper, B. (2002). Relationship of Sleep Hygiene Awareness, Sleep Hygiene Practice and Sleep Quality in University Students. Behavioral Medicine, vol.28, pp.33-6

Campbell-Sills, L., Cohan, S. L. \& Stein, M. B. (2006). Relationship of Resilience to Personality, Coping and Psychiatric Symptoms in Young Adults. Behaviour Research and Therapy, vol.44, pp.585-599.

Chong, M.A., Elias,H., Mahayuddin, R. \& Uli, J. (2009). Adjustment among First Year Students in Malaysian University. European Journal of Social Sciences, vol.8:3, pp.496-505.

Clifton, R. A., Perry, R. P., Stubbs, C. A. \& Roberts, L. W. (2004). Faculty Environments, Psychosocial Dispositions, and the Academic Achievement of College Students. Research in Higher Education, vol.45, pp.801-828.

Cutrona, C. E., Cole, V., Colangelo, N., Assouline, S. G. \& Rusell, D. W. (1994). Perceived Parental Social Support and Academic Achievement: An Attachment Theory Perspective. Journal of Personality and Social Psychology, vol.66:2, pp.369-378.

Dennis, J., Phinney, J. \& Chuateco, I. (2005). The Role of Motivation, Parental Support, and Peer Support in Academic Success of Ethnic Minority First Generation College Students. Journal of College Development, vol.46:3.

Diener E. (1984) Subjective Well-Being. Psychological Bulletin, vol.95:3, pp.542-575. [PubMed: 6399758] 5.

Diener, E., Suh E. M, Lucas, R. E. \& Smith, H.L. (1999). Subjective Well-Being: Three Decades of Progress. Psychological Bulletin, vol.123:2, pp.276-303. 
Enochs, W. K., Renk, K. (2006). Social Adjustment of College Freshmen: The Importance of Gender and Living Environment. College Student Journal, vol.40:1, pp.63-72.

Erdogan, E., Ozdogan, O., Erdogan, M. (2015).University Students' Resilience Level: The Effect of Gender and Faculty. Social and Behavioral Sciences, vol.186, pp.1262-1267.

Fischer, C. (2009). The Correlation between Grade Point Average and Copping Strategies. Retrieved on April 2014, from: webclearinghouse.net).

Fishman, J. S. (2012). Psychological Resilience, Perceived Stress, and Stress Reaction (Doctoral dissertation). Retrieved on August 2014 from http://gradworks.umi.com /35/45/3545186.html

Greblo, Z. \& Hodak, D. (2012). Socio-Demographic and Lifestyle Correlates of Health-Related Quality of Life in Croatian University Students. Applied Research in Quality of Life, vol.8:4, pp.493-509.

Holahan, C. J., Valentiner, D. P. \& Moos, R. H. (1995). Parental Support, Coping Strategies and Psychological Adjustment: An Integrative Model with Late Adolescents. Journal of Youth and Adolescence, vol.24:6, pp.633-648.

Jawahir, K. \& Kazmi, U. R. (2013). Psychological Resilience and Depression among Institutionalized and Community Residing Elders (Unpublished master`s thesis). Lahore College for Women University, Lahore, Pakistan.

Jemal, J. (2012). Asssessing Major Adjustment Problems of Freshman Students in Jimma University. Ethiop. J. Educ. \& Sc, vol.7:2.

Juozulynas, A., Cemerych, E. (2005). Evaluation of the Quality of Life of Murses. Sveikatos Mokslai, vol.1, pp.71-74.

Kabtamu, A. (2009). Major Problems Encountered by Non-Boarding College Students: Focus on Assela College of Teacher Education Students. The Ethiopian Journal of Education, vol.XXIX:2, pp.103-130.

Lama, M. (2010) Adjustment of College Freshman: The Importance of Gender and Place of Residence. International Journal of Psychological Studies, vol2:1, pp.142- 150. 
Lundgren, D. C. \& Schwab, M. R. (1979). The Impact of College on Students: Residential Context, Relations with Parents and Peers, and Self-Esteem. Youth and Society, vol.10:3, pp.227-236.

Madhuchandra, M. K., Srimathi, N.L. (2017). Psychological Health and Psychological Illness among College Students. International Journal of Informative \& Futuristic Research (IJIFR), vol.4:7, pp.6609-6616.

Mao, C. Y. W. \& Mei, C. (2008). Adjustment of Freshman College Students: A Longitudinal Study Using Longitudinal Rasch Model, vol.40:04, pp.427-435.

Masten, A. S. (1994). Resilience in Individual Development: Successful Adaptation Despite Risk and Adversity. In M. C. Wang \& E.W. Gordon (Eds.), Educational Resilience in Inner-city America: Challenges and Prospects (3-25). Hillsdale, NJ: Lawrence Erlbaum.

Mowbray, D. (2011). Resilience and Strengthening Resilience in Individuals. Management Advisory Service.

Moore, L. (2006). Family Dynamics and Students' Characteristics as Predictor of Under-Graduate College Student Adjustment. (Masters thesis, University of North Texas, Texas, USA).

Mudhovozi, P. (2012). Social and Academic Adjustment of First Year University Students, $J$ SocSci, vol.33:2, pp.251-259.

Pennebaker, J.W., Colder, M. \& Sharp, L.K. (1990). Accelerating the Coping Process. Journal of Personality and Social Psychology, vol.58, pp.528-537.

Pike, G.R. (2009) The Differential Effects of On- and Off- Campus Living Arrangements On Students' Openness to Diversity, 46(4), Indianapolis, Indiana UniversityPurdue University.

Pilcher, J. J., Ott, E. S. (1998). The Relationships between Sleep and Measures of Health and Well-Being in College Students: A Repeated Measures Approach. Behav Med, vol.23, pp.170-8.

Quinn, S. (2003). Inadequate Sleep Hygiene Practices: Level of Community Awareness. Can J Res Ther, vol.9, pp.21-9. 
Rice, F. P. (1999). The Adolescent: Development, Relationships and Culture. Boston: Allyn and Bacon.

Rinn, A. N. (2004). Academic and Social Effects of Living in Honors Residence Halls. Journal of the National Collegiate Honors Council, vol.5:2, pp.67-79.

Rouse, K. A., Ingersoll, G. M., \& Orr, D. P. (1998). Longitudinal Health Endangering Behavior Risk among Resilient and Non-Resilient Early Adolescents. Journal of Adolescent Health, vol.23:5, pp.297-302.

Ruzevicius, J. (2006). Quality of Education as a Factor of Life's Quality. Global Safety of Commodity and Environment Life. Quality of Life: Proceedings of the $15^{\text {th }}$ Symposium of IGWT, vol.1, pp.50-54.

Sabbah, I., Sabbah, H., Khamis, R., Sabbah, S., Droubi, N. (2013). Health Related Quality of Life of University Students in Lebanon: Lifestyles Behaviors and Socio-Demographic Predictors, vol.5:7A4, pp.1-12.

Sharda, R. (2003). A Study of Adjustment Problems of Female Students of H.P. University Residing in Hostel in Relation to their Mental Health. M.Ed. Unpublished Dissertation in Education, Himachal Pradesh University Shimla.

Sharma, M. (2013). Adjustment of New Boarders in Girls Hostels of Himchal Pradesh University in Relation to their Mental Health.

Tuna, M. E. (2003). Cross-Cultural Differences in Coping Strategies as Predictor of University Adjustment of Turkish and U.S. Students. (Unpublished Doctoral Dissertation, Middle East Technical University). Retrieved from: td.lib.metu.edu.tr/ upload /3/579318/index.pdf.

Urani, A., Millre, S. \& Johoson, J. (2003). Home Sickness in Socially Anxious First Year College Students. College Student Journal, vol.15:4, pp.55-60.

Watton, S. (2001). The First Year Experience of New Students at Memorial University. Center For Instructional Analysis and Planning, Report 2001-04

Wang, A., Chen, L., Zhao, B., Yan, X. (2006). First Year Students Psychological and Behavioral Adaptation to College: The Role of Coping Strategies and Social Support. US-China Education Review, vol.3:5, pp.51-57. 
Ward Struthers, C., Perry, R. P. \& Menec, V. H. (2000). An Examination of the Relationship among Academic Stress, Coping, Motivation, and Performance in College. Research in Higher Education, vol.41:5, pp.581-592.

Ware, J. E., Snow, K. K., Kosinski, M. \& Gandek, B. (1993). SF-36 Health Survey: Manual \& Interpretation Guide. Lincoln: Quality Metric Incorporated.

Wasonga, T., Christman, D. E. \& Kilmer, L. (2003). Ethnicity, Gender and Age: Predicting Resilience and Academic Achievement among Urban High School Students. American Secondary Education, vol.32:1, pp.62-75.

World Health Organization Quality of Life Assessment Group. (1998). Development and Psychometric Properties. Social Science and Medicine, 46, 17.

Windle, G., Markland, D. A. \& Woods, B. (2008). Examination of a Theoretical Model of Psychological Resilience in Older Age. Aging \& Mental Health, vol.12:3, pp.285-292.

Wintre, M. G. \& Yaffe, M. (2000). First-Year Students' Adjustment to University as a Function of Relationships with Parents. Journal of Adolescent Research, vol.15:1, pp.9-37.

Yalew, E. (2003). Causes of Student Attrition in Bahir Dar University: Qualitative and Quantitative Analysis. The Ethiopian Journal of Education, vol.XXIII:1, pp.31-66.

Yau, (2012). Adjusting to University; The Hong Kong Experience. Journal of Higher Education Policy and Management, vol.34:1, pp.15-27.

Daniya Hasan was Student in the Department of Applied Psychology, Lahore College for Women University (LCWU), Lahore.

Umm E Rubab Kazmi is Lecturer in the Department of Applied Psychology, Lahore College for Women University (LCWU), Lahore.

Kanzal Jawahir was Student in the Department of Applied Psychology, Lahore College for Women University (LCWU), Lahore. 